\title{
Znaczenie Republiki Azerbejdżanu w kontekście bezpieczeństwa energetycznego
}

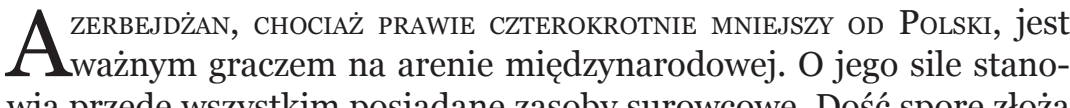
wią przede wszystkim posiadane zasoby surowcowe. Dość spore złoża gazu ziemnego i ropy naftowej są kartą przetargową o ogromnej sile. Szczególnie w okresie kryzysu gospodarczego i wręcz rozpaczliwego poszukiwania nowych źródeł energii przez Unię Europejską. Stawia to władze w Baku przed dużą szansą na poprawę swojej pozycji wśród państw Kaukazu Południowego i Azji Centralnej. Zasoby Azerbejdżanu, ulokowane w większości na dnie Morza Kaspijskiego, odgrywają znaczącą rolę w kontekście bezpieczeństwa energetycznego kontynentu europejskiego, a w szczególności państw bałkańskich oraz środkowoeuropejskich, ale także swojego najbliższego partnera, czyli Turcji. Jednakże możliwości i korzyści z nich wynikające będą skutecznie niwelowane oraz osłabiane przez politykę Federacji Rosyjskiej, która będzie chciała w ten sposób chronić swoje własne interesy reprezentowane przez eksportowego monopolistę - Gazprom.

Według danych udostępnionych przez brytyjską firmę BP, azerbejdżańskie zasoby gazu ziemnego wynoszą 1,3 bln $\mathrm{m}^{3}$, co daje $0,6 \%$ ogólnych zasobów światowych. Natomiast wydobycie w 2011 r. wyniosło $14,8 \mathrm{mld} \mathrm{m}^{3}$, czyli $0,5 \%$ produkcji światowej, z czego $8,2 \mathrm{mld} \mathrm{m}^{3}$ zostało przeznaczone na rynek wewnętrzny ${ }^{1}$. Dla porównania należy dodać, że największy producent gazu ziemnego na świecie - Federacja Rosyjska posiada zasoby rzędu 44,6 bln $\mathrm{m}^{3}$, co daje 21,4\% zasobów światowych. W $2011 \mathrm{r}$. w FR wskaźnik wydobycia sięgną 607 mld m³. Jeżeli chodzi o drugi najważniejszy surowiec energetyczny - ropę naftową, to jego zasoby w Azerbejdżanie wynoszą dokładnie miliard ton (ok. 7 mld baryłek), czyli o,4\% ogółu dostępnych i rozpoznanych zasobów tego surowca. W $2011 \mathrm{r}$. produkcja ropy naftowej w tym kraju wyniosła 45,6 mln ton (1,1\% produkcji światowej), z czego 3,6 mln zo-

${ }^{1}$ Dla porównania, zapotrzebowanie na gaz ziemny dla Polski w $2011 \mathrm{r}$. wyniosło 15,4 mld m³; BP, Statistical Review of World Energy, June 2012, s. 20, http://www. bp.com/sectionbodycopy.do?categoryId=7500\&contentId=7068481, 30.12.2012 r. 
stało wykorzystane przez rynek wewnętrzny. Porównując, dla Arabii Saudyjskiej (największego producenta ropy naftowej na świecie) te wskaźniki przedstawiają się następująco: zasoby są szacowane na 36,5 mld ton (16,1\% zasobów światowych), a wydobycie w 2011 r. wyniosło 525 mln ton (13,2\% wydobycia światowego) ${ }^{2}$.

Pozycja Azerbejdżanu jako gazowego potentata wiąże się głównie z lansowaną przez UE koncepcją Południowego Korytarza Gazowego ${ }^{3}$. Dodatkowo, nowa strategia energetyczna Europy na lata 2011-2020 podkreśla potrzebę promowania konkurencyjności unijnego wewnętrznego rynku energetycznego poprzez dywersyfikację dróg transportu, źródeł energii i operatorów rynkowych, jak również poszerzania stosunków z krajami będącymi głównymi dostawcami oraz krajami tranzytowymi. Parlament Europejski w uchwalonej przez siebie rezolucji wzywa Komisję Europejską i zainteresowane państwa członkowskie do dalszych prac na rzecz wdrażania unijnego Południowego Korytarza Gazowego, zwłaszcza projektu gazociągu Nabucco, który mógłby znacznie zwiększyć bezpieczeństwo dostaw gazu w Unii Europejskiej4. Uszczegóławiając, w ramach Południowego Korytarza Gazowego ma zostać wybudowany gazociąg łączący azerbejdżańskie złoża Szach-Deniz z potencjalnymi odbiorcami w Europie Środkowej i Południowo-Wschodniej. W początkowej fazie Komisja Europejska starała się przeforsować projekt Nabucco, zakładający budowę linii przesyłowej biegnącej od Morza Kaspijskiego przez Turcję, Bułgarię, Rumunię i Węgry do austriackiego Baumgarten ${ }^{5}$. Jednak okazał się on zbyt kosztowny i czasochłonny. Jego miejsce zajęły koncepcje zakładające utworzenie kilku linii przesyłowych. Wśród nich największy entuzjazm budzi projekt gazociągu transanatolijskiego TANAP, który miałby biec przez terytorium Turcji do granicy z Bułgarią. Jego przepustowość będzie się wahać w przedziale od 16 do $60 \mathrm{mld} \mathrm{m}^{3}$ gazu rocznie $^{6}$. Dla porównania, ten sam wskaźnik dla Nabucco wynosiłby

${ }^{2}$ Ibidem, s. 8-29.

${ }^{3}$ A. Jarosiewicz, Poludniowy Korytarz Gazowy Azerbejdżanu i Turcji, http://www. osw.waw.pl/pl/publikacje/komentarze-osw/2012-07-18/poludniowy-korytarz-gazowy-azerbejdzanu-i-turcji, 12.12.2012 r.

${ }_{4}$ Parlament Europejski, Nowa strategia energetyczna dla Europy 2011202O, http://eur-lex.europa.eu/LexUriServ/LexUriServ.do?uri=OJ:C:2012:099E:0064:0077:PL:PDF, 14.12.2012 r.

${ }^{5}$ Dokładny plan przebiegu gazociagu, http://www.nabucco-pipeline.com/portal/ page/portal/en/pipeline/route, 12.12.2012 r.

${ }^{6} \mathrm{~W}$ pierwszej fazie eksploatacji przepustowość miałaby wynosić $16 \mathrm{mld} \mathrm{m} \mathrm{m}^{3}$ gazu rocznie, natomiast w drugiej fazie $31 \mathrm{mld} \mathrm{m}^{3}$. A. Jarosiewicz, Potudniowy Korytarz Ga- 
ok. $60 \mathrm{mld} \mathrm{m}^{3}$. Natomiast nieustalona pozostaje kwestia ostatecznego wyboru rynków zbytu azerbejdżańskiego gazu, który trafiałby tą drogą do Europy. Konsorcjum Szach-Deniz zarządzające złożami, z których ma pochodzić surowiec, nieoficjalnie zapowiedziało, że decyzję o ostatecznym wskazaniu głównego adresata inwestycji podejmie w maju 2013 r. ${ }^{7}$ W grę wchodzą dwa warianty. Pierwszym z nich jest budowa przedłużenia gazociągu transanatolijskiego w postaci Nabucco-West. Opcja ta jest wspierana przez UE jako dająca największe szanse na dywersyfikację dostaw nośników energii. Według planów gazociąg ten miałby biec od granicy turecko-bułgarskiej do Baumgarten w Austrii ${ }^{8}$ i dostarczać surowiec na rynek środkowoeuropejski. Drugą opcją jest budowa gazociągu transadriatyckiego TAP, który zasilałby rynki Europy Południowej, głównie Włoch i państw bałkańskich ${ }^{9}$. Szansę na spełnienie wymagań stawianych przez Parlament Europejski dostrzega Komisja Europejska, na której spoczywa obowiązek zajmowania się tym aspektem bezpieczeństwa energetycznego i ekonomicznego UE. Potwierdza to wypowiedź Komisarza ds. Energii Günthera Oettingera, który nazwał azerbejdżański gaz „zbawieniem dla Europy”10. Także szef Kancelarii Prezydenta RP Jacek Michałowski, podczas spotkania z prezydentem Azerbejdżanu Ilhamem Alijewem w grudniu 2012 r., podkreślił, że współpraca z Baku jest dla UE kluczowa ${ }^{11}$. Stawia to niewątpliwie Azerbejdżan w uprzywilejowanej pozycji, gdyż jako jedyny pewny dostawca surowca w ramach Południowego Korytarza Gazowego może skutecznie oddziaływać na politykę prowadzoną przez UE i w ten sposób dążyć do realizacji własnych celów. Wiąże się to z możliwością wyboru ostatecznego rynku zbytu oraz promowaniem najbardziej opłacalnego projektu budowy gazociągu z punktu widzenia władz w Baku. Cele te sprowadzają się również do wzmacniania swojej pozy-

zowy..., op. cit.

7 W. Jakóbik, W maju 2013 roku decyzja $w$ sprawie Korytarza Poludniowego, http://ebe.org.pl/aktualnosci/europa/w-maju-2013-roku-decyzja-w-sprawiekorytarza-poludniowego.html, 12.12.2012 r.

${ }^{8}$ A. Jarosiewicz, Poludniowy Korytarz Gazowy..., op. cit.

${ }^{9}$ Ibidem.

${ }^{10}$ Press release, Commissioner Oettinger welcomes decision on "Nabucco West" pipeline, http://europa.eu/rapid/press-release_IP-12-720_en.htm\#PR_metaPressRelease_bottom, 12.12.2012 r.

${ }^{11}$ T. Grodecki, Michatowski: wspótpraca z Azerbejdżanem $w$ energetyce kluczowa dla UE, http://www.pap.pl/palio/html.run?_Instance=cms_www.pap.pl\&_PageID=1$\& \mathrm{~s}=$ infopakiet\&dz=swiat\&idNewsComp $=\&$ filename $=\&$ idnews $=86221 \&$ data $=$ infopaki et\&_CheckSum=-473415305, 12.12.2012 r. 
cji względem państw europejskich oraz Stanów Zjednoczonych, które dość silnie lobbowały na rzecz Południowego Korytarza.

Rys 1. Planowany przebieg gazociągu TANAP.

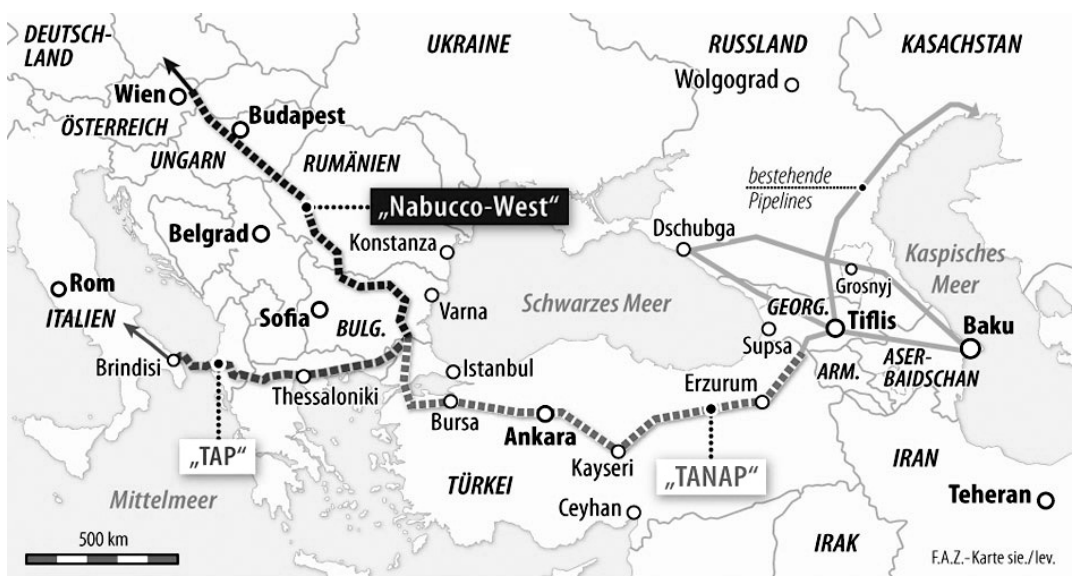

Źródło: Frankfurter Allgemeine Zeitung, Aserbaidschan liefert Gas nach Europa, http://www.faz.net/polopoly_fs/1.1802737!/image/270679850.jpg_gen/derivatives/ article_aufmacher_gross/2704679850.jpg, 30.12.2012 r.

Również Turcja jest ważnym partnerem gospodarczym Azerbejdżanu. Ich bliskość geograficzna i kulturowa dodatkowo ułatwia nawiązywanie coraz głębszych współzależności na płaszczyźnie ekonomicznej. Bliskie więzy narodów azerskiego oraz tureckiego podkreśla slogan „One Nation - Two States”, którego twórcą jest nieżyjący, były prezydent Azerbejdżanu Hejdar Alijew, i który jest często wykorzystywany przy promocji projektów będących owocem bilateralnej współpracy pomiędzy oboma państwami ${ }^{12}$. Powiązania te nie opierają się przeważnie, jak w przypadku UE, na dostawach gazu ziemnego, niezbędnego do funkcjonowania gospodarki, ale także na wspólnych projektach i przedsięwzięciach w sektorze naftowym.

W kwestii przedsięwzięć w ramach sektora gazowego należy wspomnieć, że azerbejdżański koncern państwowy SOCAR 6 października 2010 r. uzyskał pozwolenie (na okres 5 lat) od tureckiego rządu na eksport 1,2 miliarda $\mathrm{m}^{3}$ gazu na rynek wewnętrzny Turcji. Była to decyzja

${ }^{12}$ S. Kardas, Turkey and Azerbaijan: „One Nation-Two States?”, http://www. jamestown.org/programs/edm/single/?tx_ttnews\%5Btt_news\%5D=35630\&cHash= 560416055f, 15.12.2012 r. 
o znaczeniu historycznym, ponieważ umożliwiła Azerbejdżanowi dywersyfikację odbiorców gazu oraz stanowiła pierwszy krok ku wkroczeniu na rynki państw UE. Dokument ten był częścią memorandum podpisanego przez rządy obu państw w czerwcu 2010 r. i zakładał również możliwość eksportu przez terytorium Turcji 2 mld $\mathrm{m}^{3}$ „błękitnego paliwa" do Bułgarii, Grecji lub Syrii ${ }^{13}$. Natomiast już 5 stycznia następnego roku wspomniany wcześniej SOCAR, wraz z turecką firmą Turcas, uzyskał 30-letnią licencję od urzędu regulacyjnego w Ankarze na sprzedaż gazu w Turcji. Spółka SOCAR-Turcas jest ściśle podporządkowana azerbejdżańskiemu potentatowi, który posiada w niej 75\% udziałów ${ }^{14}$. Pozwalało to na stworzenie podstaw i dobrej atmosfery dla podpisania najważniejszego porozumienia pomiędzy władzami w Baku i Ankarze. 26 października 2011 r. rządy dwóch państw zawarły umowę, w której Turcja zgodziła się na tranzyt $10 \mathrm{mld}^{3}$ gazu rocznie do granicy z Grecją oraz Bułgarią. Natomiast Azerbejdżan zobowiązał się do sprzedaży $6 \mathrm{mld} \mathrm{m}^{3}$ tego surowca z drugiej fazy złoża Szach-Deniz od $2018 \mathrm{r}$. Według przedstawicieli strony tureckiej proponowane ceny były najniższe wśród oferowanych przez konkurencje ${ }^{15}$.

Wszystkie te porozumienia, umowy i memoranda wskazują na rosnącą rolę Azerbejdżanu w polityce energetycznej Turcji. Coraz większe udziały w sprzedaży gazu na jej rynku wewnętrznym i wspólne projekty w ramach Południowego Korytarza coraz bardziej zbliżają do siebie dwa „bratnie narody”. Tworzenie spółek z tureckimi firmami takimi jak Turcas czy Botas dodatkowo wzmacnia wzajemne powiązania i zależności. Jednak handel gazem ziemnym to nie jedyna dziedzina, będąca przedmiotem dynamicznie rozwijających się w ostatnim czasie, relacji turecko-azerbejdżańskich.

23 lipca 2010 r. spółka SOCAR-Botas uzyskała licencję na budowę rafinerii w Aliadze, w tureckiej prowincji Izmir. Koszt całego przedsięwzięcia został oszacowany na 5 mld dolarów. Budowa została rozpoczęta w 2012 r., a jej koniec przewidziano na rok 2014. Wykonawcy to głównie firmy zewnętrzne, takie jak Foster Wheeler, Technip

${ }^{13}$ A. Jarosiewicz, Azerbejdżański gaz $w$ drodze do Europy, Tydzień na Wschodzie, „Biuletyn Analityczny Ośrodka Studiów Wschodnich im. Marka Karpia w Warszawie” 2010, nr 34(152), s. 4-6.

${ }^{14}$ Idem, Azerbejdżan uzyskał licencje na sprzedaż gazu $w$ Turcji, Tydzień na Wschodzie, „Biuletyn Analityczny Ośrodka Studiów Wschodnich im. Marka Karpia w Warszawie" 2011, nr 1 (161), s. 12.

${ }^{15}$ Idem, Turcja i Azerbejdżan podpisały porozumienie o tranzycie gazu, http:// www.osw.waw.pl/pl/publikacje/tydzien-na-wschodzie/2011-11-09/turcja-i-azerbejdzan-podpisaly-porozumienia-o-tranzycie-g, 30.12.2012 r. 
Benelux, KTI oraz Axens. Możliwości przerobowe przyszłej rafinerii to $10 \mathrm{mln}$ ton rocznie. Będzie ona połączona z Kompleksem Petrochemicznym Petkim, w którym 51\% udziałów ma spółka-inwestor z Aliagi. Koszt wykupu akcji od państwa tureckiego 30 czerwca 2008 r. wynosił 2 mld 40 mln dolarów. Rafineria wraz z kompleksem stworzą całość, która z pewnością stanie się potentatem na rynku już nie tylko turec$\mathrm{kim}^{16}$. Dodatkowo, do 2016 r. planowane jest wybudowanie portu przemysłowego oraz dwóch elektrowni węglowych o mocy 200 i 600 MW. Mają one pomóc w obcięciu wydatków o 40\%. Koszt realizacji inwestycji to 1,6 mld dolarów. Jak powiedział dyrektor naczelny tureckiego oddziału SOCAR, Kenan Yavuz, jego firma od 2013 r. zacznie importować 1,2 mld $\mathrm{m}^{3}$ gazu z Azerbejdżanu przez Gruzję do Turcji. $\mathrm{Z}$ tej puli $500 \mathrm{mln} \mathrm{m}^{3}$ trafi do Konsorcjum Petkim, a reszta zostanie sprzedana innym odbiorcom tureckim ${ }^{17}$.

Przykłady te doskonale pokazują, jak bliska jest współpraca na linii Azerbejdżan-Turcja i jak ważną rolę odgrywają złoża położone na dnie Morza Kaspijskiego dla bezpieczeństwa ekonomicznego i energetycznego Turcji. Jej stale rosnąca pozycja w regionie Azji Mniejszej i basenie Morza Śródziemnego oraz chęć odgrywania ważnej roli jednego ze strategicznych partnerów Stanów Zjednoczonych, będą działać korzystnie na rozwój dalszej współpracy pomiędzy tymi państwami. Turcja, aby mieć możliwość zachowania obecnego statusu mocarstwa regionalnego i utrzymać duży wzrost gospodarczy, będzie musiała dalej rozwijać bilateralne stosunki gospodarcze i polityczne z Azerbejdżanem.

Azerbejdżan wraz ze swoimi zasobami surowców energetycznych oraz posiadaną infrastrukturą przesyłową stanowi ważny element w kontekście bezpieczeństwa energetycznego Gruzji. Przywódcy obu państw określają wzajemne relacje jako strategiczne i niezmiernie ważne dla całego regionu. O znaczeniu i prawdziwości tego partnerstwa może świadczyć pomoc jaką Azerbejdżan okazał Gruzji w 2006 r., kiedy rosyjski Gazprom przerwał dostawy gazu do tego kraju. Wobec tej sytuacji władze w Baku zdecydowały się na przekazanie $20 \mathrm{mln} \mathrm{m}^{3}$

${ }^{16}$ Obecnie Kompleks Petrochemiczny Petkim jest jedną z najpopularniejszych i największych korporacji oraz największym producentem wyrobów ropopochodnych w Turcji. Oficjalna strona internetowa koncernu Petkim: http://www.petkim.com.tr/ Sayfa/2/790/CORPORATE-ABOUT-US.aspx, 22.12.2012 r.

${ }^{17}$ E. Ersoy, Bloomberg, Petkim to Invest $\$ 8$ Billion on Refinery, Port, Power Plan, http://www.bloomberg.com/news/2012-10-15/petkim-to-invest-8-billion-on-refinery-port-power-plant.html, 22.12.2012 r. 
gazu zachodniemu sąsiadowi ${ }^{18}$. Był to ważny gest, biorąc pod uwagę fakt, że Gruzja jest całkowicie uzależniona od dostaw tego surowca z Federacji Rosyjskiej ${ }^{19}$. Ponadto państwa te są powiązane ze sobą gospodarczo poprzez liczne drogi tranzytu azerbejdżańskich surowców m.in. do Turcji. Pierwszym wspólnym projektem po upadku ZSRR była renowacja istniejącego już ropociągu Baku-Supsa w 1999 r., który po zmodernizowaniu jest w stanie przyjąć nawet $15 \mathrm{mln}$ ton ropy rocznie. Natomiast w 2002 r. ruszyła budowa ropociągu Baku-Tbilisi-Ceyhan o przepustowości 50 mln ton i możliwości jej powiększenia nawet do 100 mln ton. Pierwszy surowiec dotarł do końca rurociągu nad Morzem Śródziemnym w lipcu 2006 r. Następnym ważnym ze strategicznego punktu widzenia projektem gazociąg Baku-Tbilisi-Erzurum (BTE), który został oddany do użytku na przełomie 2006 i 2007 r. ${ }^{20}$ Również w kontekście planowanego Południowego Korytarza i związanego z nim gazociągu TANAP Gruzja odgrywa ważną rolę jako jedno z państw tranzytowych. Dodatkowo, wobec wcześniej wspomnianego, całkowitego uzależnienia od surowców dostarczanych przez Gazprom i innych rosyjskich dostawców, ich dywersyfikacja wydaje się być jednym z głównych celów polityki gruzińskiego rządu. W 2005 r. Gruzja kupiła od Gazpromu 1,4 mld m³ gazu co daje prawie $100 \%$ konsumpcji wewnętrznej ${ }^{21}$. Dlatego nadmierne uzależnienie od dostaw rosyjskich i próba dywersyfikacji źródeł pozyskiwania surowców energetycznych przez rząd w Tbilisi powodują coraz większy zwrot jego polityki w stronę Azerbejdżanu. Dodatkowo, profity pochodzące z opłat tranzytowych regularnie zasilają gruziński budżet i czynią w ten sposób współpracę ze wschodnim sąsiadem coraz bardziej konieczną i opłacalną.

Jednakże wzrost znaczenia Azerbejdżanu na arenie międzynarodowej nie jest korzystny dla innego potentata energetycznego - Federacji Rosyjskiej. Widać to szczególnie w prowadzonej przez nią polityce wobec całego regionu Morza Kaspijskiego. Jednym z najważniejszych jej objawów jest spór o status prawny zasobów położonych pod dnem tego akwenu. Prowadził on do licznych nieporozumień oraz napięć po-

${ }^{18}$ Zob. W. Górecki, K. Rawska-Górecka, Punkty sporne w stosunkach azerbejdżańsko-gruzińskich (lata 1989-2007), [w:] Klęska demokracji? Obszar byłego ZSRR, red. P. Grochmalski, Toruń 2010, s. 427.

${ }^{19}$ E. Wyciszkiewicz, Rosyjska polityka energetyczna w basenie Morza Kaspijskiego, [w:] Geopolityka rurociągów. Współzależność energetyczna a stosunki międzypaństwowe na obszarze postsowieckim, red. eadem, Warszawa 2008, s. 177.

${ }^{20}$ W. Górecki, K. Rawska-Górecka, op. cit., s. 430.

${ }^{21}$ E. Wyciszkiewicz, op. cit., s. 177. 
między państwami nadbrzeżnymi. Stanowi to bardzo ważną kwestię z punktu widzenia władz w azerbejdżańskich, ponieważ większość posiadanych zasobów surowcowych znajduje się w podmorskich złożach Szach-Deniz, Azeri, Czirag oraz Guneszli. Do chwili obecnej jednak nie zostało podpisane żadne porozumienie wielostronne dotyczące uregulowania statusu zasobów Morza Kaspijskiego ${ }^{22}$. Jest to zasługa przede wszystkim władz rosyjskich, które skutecznie blokowały rozwiązania wysuwane przez pozostałe państwa. Jedynym zwolennikiem proponowanych działań był przez długi czas Iran ${ }^{23}$. Przełomem okazało się porozumienie podpisane przez Federację Rosyjską oraz Kazachstan w lipcu 1998 r. Dotyczyło ono podziału dna morskiego w celu umożliwienia wykonywania suwerennych praw do eksploatacji złóż. Powyższa umowa stanowiła podstawę do podpisania podobnej ugody pomiędzy FR a Azerbejdżanem w 2002 r. Obie umowy weszły w życie do 2004 r. Jednak podziałowi zasobów Morza Kaspijskiego na sektory państwowe sprzeciwia się do dnia dzisiejszego Iran, który twierdzi, że powinny być one wykorzystywane wspólnie i jednakowo przez wszystkich uczestników sporu ${ }^{24}$.

Innym przykładem jest realizacja projektu budowy gazociągu South Stream, który ma być konkurencją dla projektu Południowego Korytarza. Ma on biec po dnie Morza Czarnego do wybrzeża Bułgarii, następnie poprzez Serbię, Węgry i Słowenię do Włoch ${ }^{25}$. Przedsięwzięcie to ma na celu niedopuszczenie do zwiększenia dywersyfikacji energetycznej UE i wzrostu znaczenia państw korzystających z zasobów Morza Kaspijskiego jako potencjalnych konkurentów Gazpromu. Według specjalistów projekt ten jest zupełnie nieopłacalny i niesienie ze sobą ogromne koszty, które, w porównaniu z dochodami, w wieloletniej perspektywie mogą okazać się większe. Dodatkowo, „Południowy Strumień” ma powiększyć liczbę odbiorców rosyjskiego gazu o państwa bałkańskie i doprowadzić stopniowo do ich uzależnienia od tego kierunku dostaw. Opłacalność tego projektu w wątpliwość podaje dodatkowo nadpodaż surowców energetycznych na rynku europejskim oraz determinacja Komisji Europejskiej, która wraz z przyszłymi pań-

${ }^{22}$ E. Wyciszkiewicz, op. cit., s. 154.

${ }^{23}$ Ibidem, s. 152.

${ }^{24}$ Ibidem, s. 154 .

${ }^{25}$ Oficjalna strona internetowa projektu South Stream, http://www.south-stream. info/en/pipeline/route/, 30.12.2012 r. 
stwami tranzytowymi oraz odbiorcami stara się za każdą cenę doprowadzić do realizacji koncepcji pożądanego Południowego Korytarza ${ }^{26}$.

Rys. 2. Planowany przebieg gazociągu South Stream.

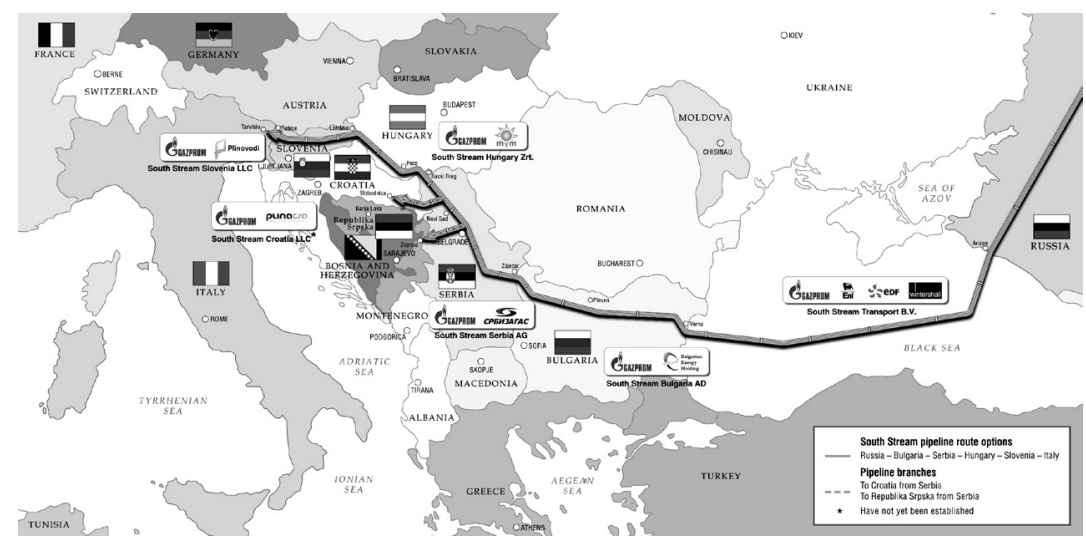

Źródło: Oficjalna strona internetowa konsorcjum South Stream, http://www.southstream.info/fileadmin/f/mapd/eng/partnership_eng.jpg, 30.12.2012 r.

Równie ważną kwestią jest współpraca gospodarcza pomiędzy Azerbejdżanem a Federacją Rosyjską, w szczególności ta dotycząca gazu ziemnego i ropy naftowej. 5 września 2010 r. rosyjski monopolista Gazprom podpisał w Baku umowę, na mocy której podwoił zakup azerbejdżańskiego gazu z $1 \mathrm{mld} \mathrm{m}^{3} \mathrm{w} 2010 \mathrm{r}$. do $2 \mathrm{mld} \mathrm{m}^{3} \mathrm{w}$ roku następnym. Umowa ta przewidywała także elastyczne zwiększenie stawek kupowanego surowca w zależności od potrzeb ${ }^{27}$. Przedsięwzięcie to ma na celu odciąganie Azerbejdżanu od projektu Południowego Korytarza poprzez oferowanie wysokich stawek, z rosyjskiego punktu widzenia mało opłacalnych, jednak realizujących strategiczny cel polityki rządu w Baku, którym jest dywersyfikacja partnerów eksportowych. Dodatkowo, Moskwa stara się wpłynąć na swego południowego sąsiada poprzez utrzymywanie zależności surowcowej i przejmowanie aktywów energetycznych oraz infrastruktury w innych państwach Kaukazu Południowego. Doskonałym przykładem jest Gruzja, która

${ }^{26} \mathrm{~S}$. Kardaś, E. Paszyc, Za wszelka cenę: Rosja rozpoczyna budowę South Streamu, „Komentarze OSW” 2012, nr 98.

${ }^{27}$ Gazprom podwoi zakupy gazu w Azerbejdżanie, „Biuletyn Analityczny OSW” 2010, $\mathrm{nr}$ 29(147), s. 7. 
odgrywa niebagatelną rolę w planowanym projekcie TANAP oraz już istniejącej sieci przesyłowej. Aby osłabić jej pozycję, Gazprom umiejętnie manipuluje cenami sprzedawanego na gruziński rynek gazu. Stara się w ten sposób również zniechęcić Tbilisi do podejmowania kroków szkodzących jego interesom ${ }^{28}$. Dominacja energetyczna Federacji Rosyjskiej jest niekwestionowana. Obecnie posiada 12,1 mld ton rezerw ropy naftowej, a jej produkcja sięga $511 \mathrm{mln}$ ton rocznie. Jest także najzasobniejszym krajem na świecie, jeśli chodzi o gaz ziemny. Przytoczone dane doskonale przedstawiają siłę argumentów, która posiada rząd w Moskwie oraz Gazprom jako przedłużenie i uzupełnienie prowadzonej przez nią polityki zagranicznej.

Podsumowując, Azerbejdżan zaczyna odgrywać coraz większą rolę jako potencjalny dostawca surowców energetycznych do państw europejskich, Turcji, Gruzji oraz staje się realnym zagrożeniem dla zapędów monopolistycznych rosyjskiego Gazpromu. Ma to związek z ekspansją Państwowej Spółki Naftowej Republiki Azerbejdżan (SOCAR) już nie tylko na wcześniej wspomniane rynki, lecz także na te znajdujące się „pod nosem” konkurencji. Doskonałym przykładem jest tu Ukraina oraz państwa Azji Centralnej. Dodatkowo, w nadchodzącym okresie główny rywal Azerbejdżanu na tym polu, Federacja Rosyjska, może spotkać się z licznymi przeszkodami oraz problemami natury wewnętrznej. Najważniejszym z nich wydaje się szybki wzrost rosyjskiej gospodarki o ok. 6\% rocznie co według specjalistów może prowadzić do takiej sytuacji, w której Gazprom nie będzie w stanie zaspokoić jej surowcowego popytu ${ }^{29}$. Na niekorzyść Moskwy działają również wysokie wydatki na nieopłacalne z ekonomicznego punktu widzenia projekty typu South Stream, czy odrzucenie strategii inwestowania w łupki gazowe na rzecz łupków ropy naftowej. Ponadto działania podjęte przez UE oraz prowadzona przez nią polityka dywersyfikacji źródeł dostaw nośników energii dodatkowo pogarszają położenie Federacji Rosyjskiej.

Wszystkie te czynniki, a przede wszystkim osłabienie pozycji głównego dostawcy gazu ziemnego do Europy, czyli Federacji Rosyjskiej, działają na korzyść Azerbejdżanu, który z roku na rok staje się coraz silniejszy gospodarczo. Ze wzrostem ekonomicznym łączy się również zwiększenie siły oddziaływania, co doskonale wykorzystują władze w Baku, forsując korzystne dla swojego kraju rozwiązania oraz projek-

${ }^{28}$ E. Wyciszkiewicz, op. cit., s. $178-180$.

${ }^{29}$ J. Biłałek, A. Oleksiuk, Gospodarka i geopolityka. Dokąd zmierza świat?, Warszawa 2009, s. 81. 
ty energetyczne, a budowa Południowego Korytarza Energetycznego może okazać się tylko początkiem gospodarczej ekspansji tego kaukaskiego państwa.

\section{SUMMARY}

The ARTiCle is about CONTEMPorary Role of AzerbaiJAn on the European and Asian countries' energetic market. The author describes projects and trends connected with economic expansion among Azerbaijani companies. One of them, project of the Southern Energetic Corridor, is the most important for the European Union, because of its energy priorities. The biggest opponent of Azerbaijan is Russian Federation, which is trying to force solutions beneficial only for themselves. Azerbaijani sources of energy are hugely important for the nearest neighbors: Turkey and Georgia. In a few years Azerbaijan could become an energy tycoon and would dictate their own solutions like Russia does today.

\section{NOTA O AUTORZE}

Mateusz Garbaciak [garbaciak.mateusz@gmail.com] - jest studentem II roku studiów I stopnia na kierunku Stosunki Międzynarodowe na WNPiD UAM oraz I roku Wschodoznawstwa w Instytucie Wschodnim UAM. Interesuje się kwestiami politycznymi oraz gospodarczymi związanymi z obszarem postradzieckim, w szczególności państwami Kaukazu Południowego oraz Ukrainą. 